\title{
THE CLASSIFICATION OF THE MASA GROUP OF LANGUAGES*
}

\author{
Aaron Shryock \\ University of California, Los Angeles
}

\begin{abstract}
The Chadic family of languages comprises approximately 140 languages classified into three major branches: West Chadic, Biu-Mandara, and East Chadic. Newman [1977b] has proposed an additional, fourth branch of Chadic consisting of the Masa group of languages, previously classified in the Biu-Mandara branch. This article provides supporting evidence for Newman's classification of the Masa group as a fourth branch by demonstrating that this group does not exhibit the phonological, lexical, and morphological innovations characteristic of the BiuMandara branch. It follows from the absence of these innovations that there is no evidence for the classification of the Masa group in the Biu-Mandara branch.
\end{abstract}

\section{Introduction}

Chadic languages, of which there are approximately 140, are spoken in southern Niger, northern Nigeria, northern Cameroon, and western and central Chad [Newman 1977b, 1990, 1992]. Since the first comprehensive classification of these languages [Greenberg 1963], there has been considerable disagreement in the literature about the internal subclassification of Chadic. Currently, there is a consensus that the Chadic family is composed of three major branches: West Chadic, Biu-Mandara or Central Chadic, and East Chadic [Newman 1977b, 1992; Jungraithmayr and Shimizu 1981; Jungraithmayr and Ibriszimow 1994]. However, Newman [1977b] has proposed an additional, fourth branch of Chadic consisting of the Masa group of languages. This group was previously classified in the BiuMandara branch of the family [Hoffmann 1971, Newman 1978]. In response to Newman's proposal, Tourneux [1990] presented evidence in support of the

\footnotetext{
* I would like to thank Russell Schuh, Kimberly Thomas, Robert Botne, and an anonymous reviewer for their assistance and insightful comments.
} 
subgrouping of Masa in Biu-Mandara. This subclassification has been maintained by Jungraithmayr [1981], Jungraithmayr and Shimizu [1981], Barreteau [1987], and Jungraithmayr and Ibriszimow [1994] in their studies of the Chadic family.

In this paper I provide supporting evidence for the classification of the Masa group as a fourth branch of the Chadic family. I demonstrate that the Masa group does not exhibit the phonological, lexical, and morphological innovations characteristic of the Biu-Mandara branch. It follows from the absence of these innovations that there is no evidence for the subclassification of this group in BiuMandara. Thus, I conclude that the Chadic family is composed of four branches as proposed by Newman [1977b].

The paper is organized as follows. In section 2 I present an overview of the Chadic family. I outline the internal composition and subclassification of the BiuMandara languages and the languages of the Masa group. I then summarize the major classifications of the Chadic languages in section 3. The principal arguments regarding the position of the Masa group in the Chadic family are also considered. In sections 4 through 6, I present several phonological, lexical, and morphological innovations of the Biu-Mandara branch and demonstrate that these innovations are not attested in the Masa group of languages. I provide an appendix containing a list of 204 words reconstructed for the Proto-Masa group in order to substantiate the arguments presented in this paper as well as to encourage further comparative research.

\section{The Chadic family}

As noted above, the Chadic family consists of three major branches: West Chadic, Biu-Mandara, and East Chadic [Newman 1977b, 1990, 1992]. In the West Chadic branch there are approximately 64 languages spoken primarily in northern and northwestern Nigeria. Hausa, the predominant Chadic language, belongs to the West Chadic branch. Hausa has over 40 million speakers located primarily in northern Nigeria but it extends west and north into Niger. The languages of the Biu-Mandara branch are spoken in northeastern Nigeria, northern Cameroon, and westernmost Chad. There are at least 68 languages in this branch. The estimated 30 languages comprising the East Chadic branch are spoken primarily in western and central Chad. Finally, the Masa group is composed of nine closely related languages spoken along the border of northern Cameroon and southwestern Chad. In the remainder of this section, I outline in more depth the composition and internal classification of the Biu-Mandara branch and the Masa group.

2.1. Biu-Mandara. The internal classification of the Biu-Mandara branch (BM) is schematized in (1) following Newman [1977b]. According to Newman, BiuMandara is comprised of two subbranches, ' $A$ ' and ' $B$ '. The Biu-Mandara-A subbranch (BM-A) is comprised of eight groups. The Biu-Mandara-B subbranch (BM-B) includes the Musgu, Kotoko, and Gidar groups. 
(1) The Biu-Mandara branch

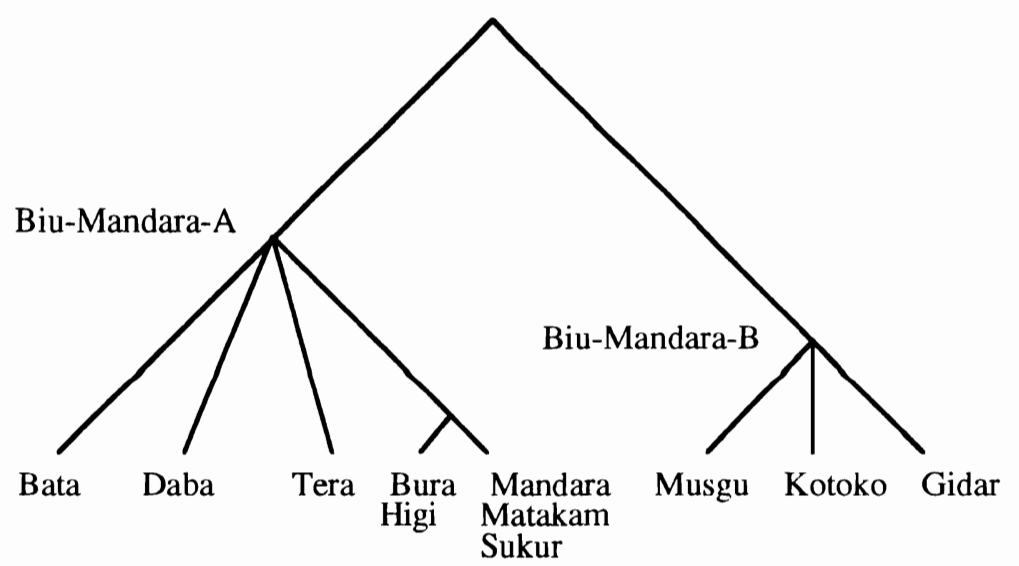

In Newman's 1990 classification of the Chadic languages, the Gidar group is subclassified as a separate, third subbranch in Biu-Mandara. The innovations presented for the Biu-Mandara-B subbranch in this paper hold for the Gidar group as well as the Musgu and Kotoko groups. Since the position of Gidar as a third subbranch may be questioned, I follow Newman's 1977b subclassification of BiuMandara into two branches. Regardless of the position of Gidar in the BiuMandara branch, the principal argument of this paper remains the same: the Masa group of languages does not exhibit the innovations characteristic of the BiuMandara languages.

2.2. The Masa group. The Masa group consists of nine closely related languages spoken in southwestern Chad and contiguous regions of northern Cameroon. The languages comprising the group are subclassified into two subgroups, 'north' and 'south' [Dieu and Renaud 1983, Tourneux 1990]. The northern subgroup consists of Masa, Musey, Marba, and Monogoy [Barreteau 1987, Tourneux 1990]; the southern subgroup of Zime (Mesme), Peve, Hede, and Ngide [Jungraithmayr 1978a, Hufnagel 1986, Noss 1990]. Zumaya is provisionally classified as separate from these principal subgroups following Barreteau [1987]. The internal subclassification of the group is summarized in (2).

As noted above, the northern subgroup consists of Masa, Musey, Marba, and Monogoy. Masa has approximately 180,000 speakers situated in the Mayo-Kebbi prefecture of southwestern Chad and in northern Cameroon in the Mayo-Danay Division of the Far North Province [Caiitucoli 1983]. There are approximately 150,000 speakers of Musey [Platiel 1968; R. Duncanson, p.c.], of whom approximately 120,000 live in the Mayo-Kebbi prefecture situated between Fianga and Kelo, the remaining 30,000 in the Mayo-Danay Division of the Far North Province in Cameroon. The approximately 80,000 speakers of Marba, also known 
as Azumeina [Price 1968], reside primarily in the Mayo-Kebbi prefecture, north of Kelo. Finally, Monogoy has an estimated 5,000 speakers located in the MayoKebbi prefecture northwest of Kelo [R. Duncanson, p.c.]. The Marba and Monogoy are culturally distinct groups, but linguistically they may be similar enough to warrant being classified as dialects of a single language [R. Duncanson, p.c.; S. Lazicki, p.c.].

(2) The languages of the Masa group

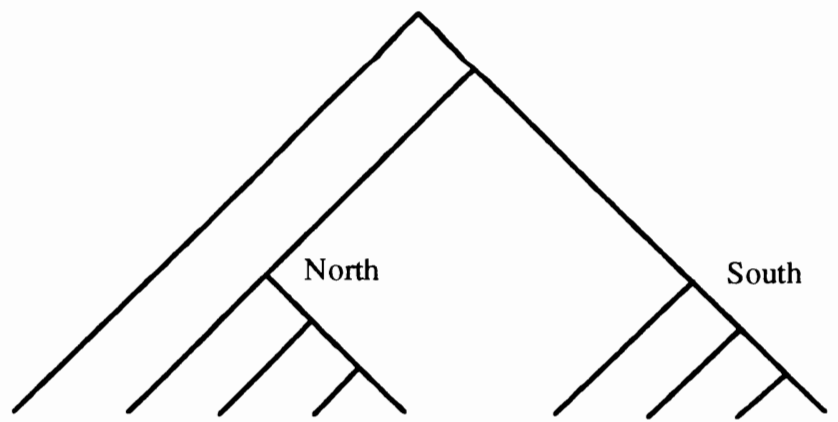

Zumaya Masa Musey Marba Monogoy Zime Peve Hede Ngide

(3) Map for Masa, Musey, Marba, and Monogoy

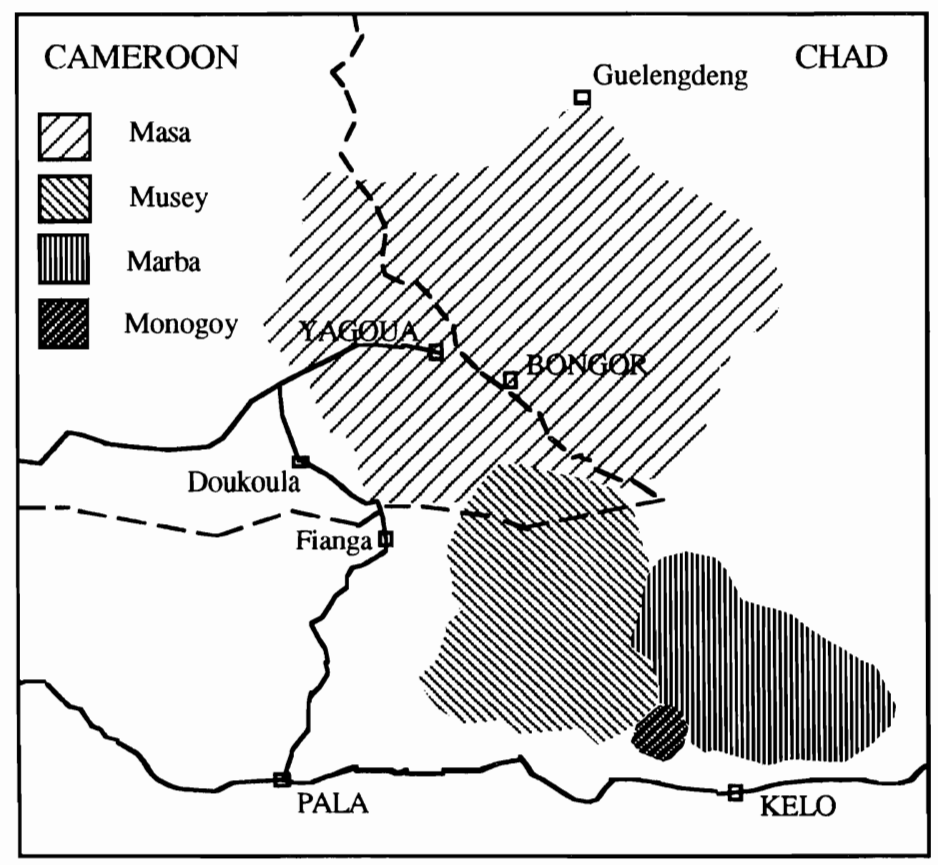


The southern subgroup consists of Zime (Mesme), Peve, Hede, and Ngide [Jungraithmayr 1978a, Hufnagel 1986, Noss 1990]. Zime, which has an estimated 30,000 speakers [Hufnagel 1986, Kieschke 1990, Noss 1990], is spoken in the Mayo-Kebbi prefecture, immediately east of Kelo, Chad. Peve is also spoken in the Mayo-Kebbi prefecture, west of Pala in a region which extends into the neighboring area of Cameroon. It has approximately 30,000 speakers [Venberg 1975]. Hede, with an estimated 35,000 speakers [Noss 1990], is spoken in an area to the immediate east of the Peve speaking area [Hufnagel 1986, Noss 1990]. Lamé or Dzəpaw is the southernmost dialect of Hede, spoken in Cameroon east of the Bouba Njidda National Forest Reserve [Sachnine 1982]. Finally, Ngide is spoken to the east of Pala and has an estimated 5,000 speakers [Noss 1990; R. Duncanson, p.c.]. Hede and Ngide are the most closely related members of the southern subgroup. Noss [1990] has questioned the status of Ngide as a language separate from Hede, but also notes that the Ngide people consider themselves culturally and linguistically distinct.

(4) Map for Zime, Peve, Hede, and Ngide

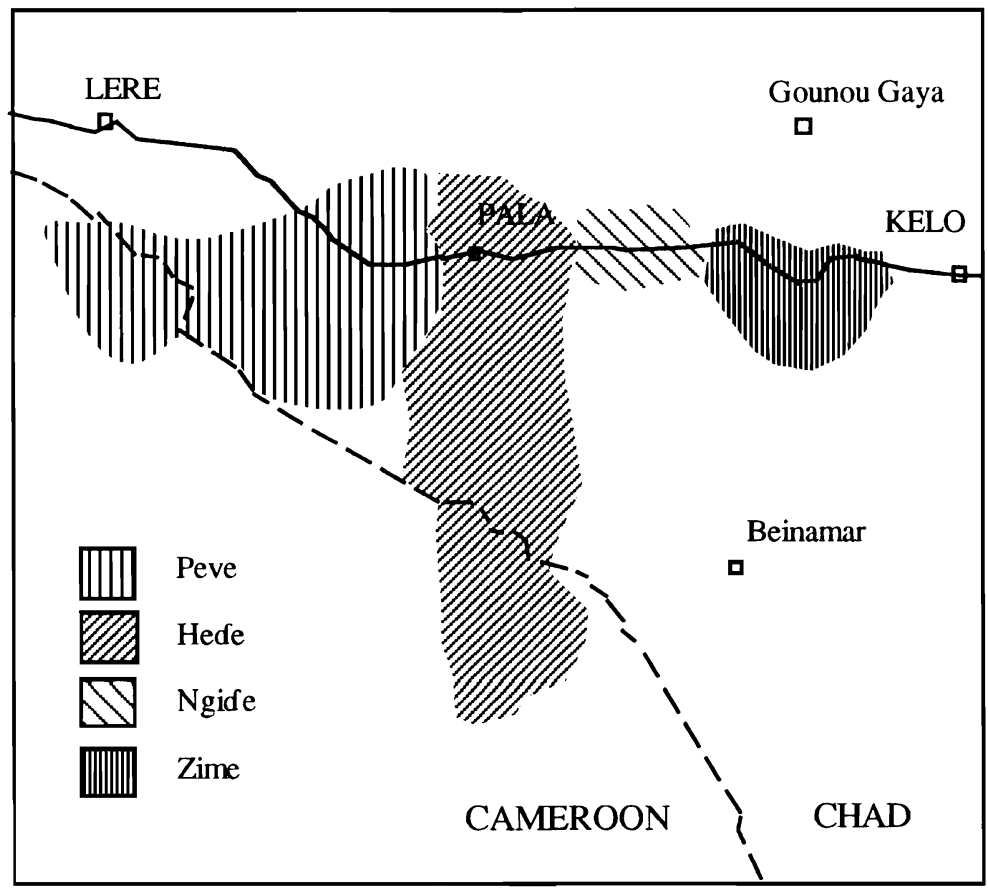

Zumaya has only a few remaining speakers [Barreteau 1987]. Its classification in the group is unclear because the language has not been well documented. 


\section{Overview of Chadic classification}

3.1. Classifications of the Chadic languages. Greenberg [1963] put forward the first comprehensive classification of the languages of the Chadic family, classifying the languages in nine groups and demonstrating their unity as a family. Newman and Ma's [1966] in-depth comparative study of the Chadic languages demonstrated more conclusively the genetic unity of the family. They also provided evidence for the subclassification of four of Greenberg's nine groups. They classified groups 1 and 9 as a single subgroup which they referred to as "Plateau-Sahel" and groups 3 and 6 as a second subgroup referred to as "BiuMandara". Hoffmann [1971] placed the remaining five groups of Greenberg [1963] in Newman and Ma's "Biu-Mandara", thereby classifying all the Chadic languages into two major branches. Subsequently, in 1974, Newman [1978] proposed that Plateau-Sahel be split into two separate branches coordinate with the Biu-Mandara branch, introducing the terms "West Chadic" and "East Chadic" to refer to the two groups comprising the Plateau-Sahel branch, formerly Greenberg's groups 1 and 9, respectively. Finally, Newman [1977b] proposed that the Masa group of languages constitutes a fourth branch of Chadic, coordinate with the other three major branches. The Masa group corresponds to Greenberg's group 8 and was previously classified as part of the Biu-Mandara branch [Hoffmann 1971, Newman 1978]. These classifications are summarized in (5).

(5) The major classifications of the Chadic languages

\begin{tabular}{|c|c|c|c|c|c|}
\hline Greenberg [1963] & 1 & 9 & $3 \& 6$ & $2,4,5, \& 7$ & 8 \\
\hline Newman \& Ma [1966] & \multicolumn{2}{|c|}{ Plateau-Sahel } & Biu-Mandara & & \\
\hline Hoffmann [1971] & \multicolumn{2}{|c|}{ Plateau-Sahel } & \multicolumn{3}{|c|}{ Biu-Mandara } \\
\hline Newman [1978] & West & East & \multicolumn{3}{|c|}{ Biu-Mandara } \\
\hline Newman [1977b] & West & East & \multicolumn{2}{|c|}{ Biu-Mandara } & Masa \\
\hline
\end{tabular}

3.2. Classification of the Masa group and Musgu. The Masa group of languages has been considered to be closely related to Musgu, a Biu-Mandara language [Westermann and Bryan 1952, Meyer-Bahlberg 1972, Caprile and Jungraithmayr 1973]. The close relationship between these languages appears to be based primarily on the geographic proximity of Musgu and the Masa language as well as on typological and lexical similarities between these two languages. MeyerBahlberg [1972], for instance, noted similarities between Musgu and Masa in the manner in which they form various syntactic constructions such as relative clauses and comparatives. Furthermore, she noted lexical and grammatical resemblances between the languages. 
Despite the similarities reported between Masa and Musgu, Greenberg [1963] classified Masa and the other languages of the Masa group as a distinct group from Musgu, in groups 8 and 7, respectively. Newman and Ma [1966] did not place the Masa and Musgu groups with any of the other groups in their classification of Chadic, leaving both outside the Plateau-Sahel and Biu-Mandara groups. As noted above, Hoffmann [1971] then classified the Masa group and Musgu together as part of the Biu-Mandara branch, while Caprile and Jungraithmayr [1973] classified them as a single group. In a later classification, Newman [1978] distinguished two subbranches of the Biu-Mandara branch, designated ' $A$ ' and 'B', and, in keeping with the consensus of a close genetic relationship, he placed the Masa group and Musgu in the same subbranch, Biu-Mandara-B.

In 1977, Newman rejected the conventional acceptance of a close relation between the Masa group and Musgu, proposing instead that the Masa group be removed from the Biu-Mandara branch and provisionally classified as a fourth branch of Chadic. He noted that the primary argument for removing the Masa group from Biu-Mandara was that the Masa group does not exhibit the sound change Proto-Chadic $* S>*$ characteristic of the Biu-Mandara branch [Newman $1977 \mathrm{a}, \mathrm{b}] .{ }^{*} \mathrm{~S}$ represents a sibilant distinct from Proto-Chadic ${ }^{*}$, possibly [ $]$ ]. Furthermore, Newman noted that he could not find any features of the Masa group which would justify its subclassification in the West or East Chadic branches. Consequently, he provisionally classified the group as a separate branch. It is important to note that Newman's subclassification was based on the identification of shared innovations. In the absence of shared innovations among languages or language groups, no subclassification can be inferred.

In response to Newman [1977b], Tourneux [1990] argued for the subclassification of the Masa group as part of Biu-Mandara-B. Tourneux noted three sound correspondences characteristic of the Masa group: Proto-Chadic ${ }_{s}$ corresponds to [s], Proto-Chadic * $r$ to [1], and Proto-Chadic *d to [r] in intervocalic position. Note that Tourneaux's Proto-Chadic *s is equivalent to Newman's Proto-Chadic ${ }^{*} S$. Tourneux compared these correspondences with other Chadic languages and, specifically, with Musgu. He observed that these sound correspondences occur elsewhere in the Chadic family and, more importantly, in Musgu. However, the fact that the Masa group and Musgu share these sound correspondences does not mean that these languages should be subclassified in the same branch of the family. Tourneux illustrated this point well by demonstrating the prevalence of these sound correspondences in other branches of Chadic. If it could be shown that the Masa group and Musgu underwent these sound changes at a similar point in their history, then these correspondences could possibly be phonological innovations indicating a period of common ancestry. Tourneux did not address the relative chronology of these sound changes. In section 4, I show that these sound correspondences represent sound changes which occurred independently in the Masa group and BiuMandara. 
Tourneux also presented the findings of a lexico-statistical comparison of Musgu and four of the languages of the Masa group based on a modified Swadesh list. This comparison revealed that the Masa group languages exhibited from 37 to $41 \%$ cognancy with Musgu. Tourneux suggested that these figures indicated that the Masa group and Musgu are more closely related than Newman's subclassification recognizes. He suggested, moreover, that these findings argue for the subclassifi-cation of the Masa group as a group within Biu-Mandara. In support of this proposal, Tourneux noted that the languages of the Matakam group, a group in the A sub-branch of Biu-Mandara, share from $32 \%$ to $68 \%$ of their vocabulary. Tourneux suggested that since the Masa group and Musgu share approximately $40 \%$ of their vocabulary, it follows that the genetic relation between these languages is comparable to that noted for the languages of the Matakam group. It is not the case, however, that the percentage of cognate vocabulary represents an absolute figure with which to determine degree of subclassification. Moreover, the identification of shared innovations remains the principal method of subclassification.

In the remainder of this paper, I present several phonological, lexical, and morphological innovations characteristic of the Biu-Mandara branch and the BiuMandara-B sub-branch. I demonstrate that the Masa group of languages consistently does not share the innovations of the Biu-Mandara branch. In the absence of shared innovations, there is no evidence for the subclassification of the Masa group of languages within Biu-Mandara. Thus, the absence of the BiuMandara innovations in the Masa group supports Newman's proposal that the Masa group should be classified as a separate, fourth branch of Chadic.

\section{Phonological Innovations}

In this section, I present four historical sound changes which affected the BiuMandara languages. Two of the sound changes affected Biu-Mandara and distinguish this branch from the East and West Chadic branches. The two remaining changes affected the B subbranch of Biu-Mandara but not the A subbranch. After considering these sound changes in Biu-Mandara, I consider the corresponding historical developments in the Masa group. I demonstrate that the Masa group did not undergo the sound changes reconstructed for Biu-Mandara.

4.1. Sound changes affecting Proto-Biu-Mandara. There are two well-documented sound changes which affected Proto-Biu-Mandara (Proto-BM): ProtoChadic *b $>$ Proto-BM *v and Proto-Chadic *S > Proto-BM * [Newman 1977a,b] The first of these changes is illustrated in (6). The Proto-Chadic reconstructions presented in (6) and in subsequent discussions are from Newman [1977b]. See Appendix A for a list of language abbreviations. 
(6) Proto-Chadic $* b>$ Proto-BM $* v$

$\begin{array}{llll}\text { Proto-Chadic } & \text { BM-B } & \text { BM-A } \\ \text { *bar } & \text { 'blood' } & \mathrm{Mg} \text { fel } & \text { J vara } \\ \text { *barə } & \text { 'to give' } & \text { Lo vá, G ə+vaya } & \text { T vərə } \\ \text { *zaban } & \text { 'guinea-fowl' } & \text { Lo záawan, G zamvəna } & \text { Gs tsuvon } \\ \text { *bədi } & \text { 'night' } & \text { Lo vade } & \text { Db vudu }\end{array}$

The second sound change, Proto-Chadic $* S>$ Proto-BM $* 1$, is of particular interest because a change of this nature only occurred in Biu-Mandara [Newman 1977a,b]. This sound change is illustrated in (7). As noted earlier, Proto-Chadic *S represents a sibilant distinct from Proto-Chadic *s.

(7) Proto-Chadic $* \mathrm{~S}>$ Proto-BM $* 1$

$\begin{array}{lll}\text { Proto-Chadic } & \text { BM-B } & \text { BM-A } \\ \text { *'JaSu 'bone' } & \text { Lo ałe, G tèntén } & \text { T 'get } \\ \text { *Səmi 'ear' } & \text { Mg time, G ł̇̀má } & \text { Hi həme } \\ \text { *Səm 'name' } & \text { Lo temi } & \text { M tom } \\ \text { *San(-) 'tooth' } & \text { Lo tan, G taya } & \text { Pd tira }\end{array}$

4.2. Sound changes affecting Proto-Biu-Mandara-B. Two sound changes which affected Proto-Biu-Mandara-B include: Proto-Chadic ${ }^{*} \mathrm{r}>$ Proto-BM ${ }^{*} \mathrm{r}>$ Proto$\mathrm{BM}-\mathrm{B} * \mathrm{l}$ and Proto-Chadic $* \mathrm{~d}>$ Proto-BM $* \mathrm{~d}>$ Proto-BM-B $*_{\mathrm{r}} / \mathrm{V}_{-} \mathrm{V}$. The first of these changes is illustrated in (8).

(8) Proto-BM * $\mathrm{r}>$ Proto-BM-B *1

Proto-Chadic
*kərfi 'fish'
*pərə 'to fly'
*təra $\quad$ 'moon'
*xərə 'to steal'

BM-B

$\mathrm{Mg}$ kilif, $\mathrm{G}$ kilfi

$\mathrm{Mg}$ afili, Lo pelace

$\mathrm{Mg}$ tile, $\mathrm{G}$ tola

Mg hala, G othala
BM-A

T yurvu

Mn torə

Gd xərə

The sound change Proto-Chadic ${ }^{*} \mathrm{r}>{ }^{*}$ l applied to a significant number of BiuMandara-A languages. This sound change, however, cannot be reconstructed for Proto-BM-A. The sound change affected the Bura/Higi, Mandara, Matakam, and Daba groups of Biu-Mandara-A. It did not arise in the Tera and Bacama groups. As seen in (1) above, Bura/Higi, Mandara, Sukur, and Matakam belong to a single subbranch of Biu-Mandara-A. The Daba, Tera, and Bacama groups constitute three separate subbranches. Thus, the change occurred in two of the four subbranches of Biu-Mandara-A. The distribution of this sound change suggests that it occurred independently in these two subgroups after the split of Proto-BM-A. 
The second sound change affecting Biu-Mandara-B was Proto-Chadic $*_{\mathrm{d}}>$ Proto- $\mathrm{BM} * \mathrm{~d}>$ Proto-BM-B ${ }^{*} \mathrm{r} / \mathrm{V}_{-} \mathrm{V}$. This sound change is illustrated (9).

(9) Proto-BM *d > Proto-BM-B $*_{r} / V_{-}$V

$\begin{array}{lll}\text { Proto-Chadic } & \mathrm{BM}-\mathrm{B} & \mathrm{BM}-\mathrm{A} \\ \text { *kədəm 'crocodile' } & \mathrm{Mg} \text { kurum } & \mathrm{Mn} \text { cərwə } \\ \text { *idə } & \mathrm{Bu} \text { yil, } \mathrm{Mg} \text { arai } & \mathrm{Mt} \text { di } \\ \text { *bədi 'eye' } & \mathrm{Mg} \text { ávrìk, G bərya } & \mathrm{Lng} \text { vəji }\end{array}$

In Biu-Mandara-A, the Daba and Matakam groups exhibit this sound change. Several languages of the Bura group, including Kilba and Margi, also underwent this change. In the majority of the groups in Biu-Mandara-A, though, Proto-Chadic $*_{\mathrm{d}}$ did not change to ${ }^{\mathrm{r}}$ intervocalically.

4.3. Sound changes in the Masa group. Three sound changes reconstructed for the Proto-Masa group (Proto-MG) are of interest here: Proto-Chadic $* b>$ ProtoMG ${ }^{*} \mathrm{v}$, Proto-Chadic ${ }^{*} \mathrm{~S}>$ Proto-MG ${ }^{*} \mathrm{~s}$, and Proto-Chadic ${ }^{*} \mathrm{~d}>$ Proto-MG ${ }^{*} \mathrm{r} /$ V_V. These sound changes are illustrated in the following tables.

(10) Proto-Chadic *b $>$ Proto- $\mathrm{MG} * \mathrm{v}$

Proto-Chadic

Masa group

*bar 'blood'

$\mathrm{P}$ vūsū, $\mathrm{H}$ vursu, $\mathrm{Z}$ vursu

*bədi 'monkey'

Ma vì̀+rà, $\mathrm{Mb}$ vitra, $\mathrm{H}$ vir, $\mathrm{Z}$ vir

*ba 'mouth'

Ma vùn+nà, $\mathrm{P}$ vūn, $\mathrm{H}$ vùn, $\mathrm{Z}$ vin

(11) Proto-Chadic *S $>$ Proto-MG *S

Proto-Chadic

*'JaSu 'bone'

*aSi 'egg'

*Səm 'name'

*Sənə 'to send'
Masa group

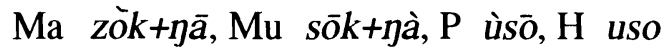

$\mathrm{Mu}$ sē+nà, $\mathrm{Mb}$ asse+na, $\mathrm{N} \int e$ ?

Ma sēm+nā, Mu sēm+má, $Z$ sem

$\mathrm{Mb}$ sun, $\mathrm{P} \int$ in, $\mathrm{H} \sin , \mathrm{N} \sin$

(12) Proto-Chadic $* d>$ Proto-MG $*_{r} / V_{-} V$

Proto-Chadic

*idə 'eye'

*kədəm 'crocodile'

*bədi

\section{Masa group}

$\mathrm{Mu}$ ì̀+rà, $\mathrm{Mb}$ ir $+\mathrm{a}, \mathrm{P} \overline{\mathbf{1}}, \mathrm{H}$ ir, $\mathrm{Z}$ ir

$\mathrm{Mu}$ hūrùm+mà, $\mathrm{P}$ hūrūm, $\mathrm{H}$ hurum, $\mathrm{N}$ hūrūm

$\mathrm{Ma}$ vì̀+rà, $\mathrm{Mb}$ vitra, $\mathrm{H}$ vir, $\mathrm{Z}$ vir 
The change Proto-Chadic $*_{\mathrm{d}}>*_{\mathrm{r}} / \mathrm{V}_{-} \mathrm{V}$ brought about a phonological contrast between ${ }^{*} r$, a flap, and ${ }^{*}$ r, a trill, in Proto-MG. The Proto-MG ${ }^{*} r$ is the reflex of Proto-Chadic ${ }^{*} \mathrm{r}$ whereas the Proto-MG ${ }^{*} \mathrm{r}$ is the reflex of Proto-Chadic intervocalic $*_{\mathrm{d}}$. After the split of Proto-Masa group into the northern and southern subgroups, the contrast between the two r's was independently lost in both subgroups. In the southern languages the $*_{r}$ merged with the ${ }^{*} r$; but in the northern languages, ${ }^{*} r$ merged with ${ }^{*}$ l. Note the correspondences in (13) for Proto-MG $*_{\Gamma}$ in contrast to the reflexes of Proto-MG ${ }^{*} \mathrm{r}$ and ${ }^{*} \mathrm{l}$ seen in (14) and (15).

(13) Proto-MG ${ }^{*} \mathrm{r}>*^{*}$ in northern subgroup, ${ }^{*} \mathrm{r}$ in southern subgroup

\begin{tabular}{|c|c|c|c|c|}
\hline Proto-Chadic & Proto-MC & & North & South \\
\hline *kərfi & $*_{k}-\mathrm{rf}-$ & 'fish' & Ma kūlùf+nà & N kérfé \\
\hline *təra & *tir & 'moon' & Ma $t \overline{1} l+t a \bar{a}$ & $\mathrm{P}$ cēr, $\mathrm{Z}$ ter \\
\hline$*_{\text {mar }}$ & *mbur & ‘oil’' & Mu mbùl+lâ & $\mathrm{H}$ mbur \\
\hline
\end{tabular}

(14) Proto- $\mathrm{MG}^{*} \mathrm{r}>{ }^{*} \mathrm{r}$

Proto-Chadic Proto-MG

*kadəm *hurum 'crocodile'

$*$ idə

*bədi

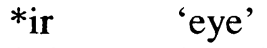

*vir
North

Mu hūrùm+mà

$\mathrm{Mb}$ irta

Ma vì̀+rà
South

$\mathrm{P}$ hūrūm

$\mathrm{H}$ ir, $\mathrm{Z}$ ir

$\mathrm{H}$ vir, $\mathrm{Z}$ vir

(15) Proto-MG *1 > *1

Proto-Chadic Proto-MG

North

South

*gol 'to watch'

$\mathrm{Mu} g o l$

*gulok 'rooster'

*wile 'to shine, flash'

Mu gògòlók+ $+\bar{a}$

$\mathrm{Mb}$ wile+da

*sal

$\mathrm{Mu}$ sal

H gól

$\mathrm{P}$ gùlòk

L wile?e

$\mathrm{H}$ sal

It is a common characteristic of languages in this area of Africa to distinguish a trill, flap, and voiced lateral. Hausa, Ngizim, and Kanuri (Nilo-Saharan), for instance, exhibit such an inventory of liquids. It is interesting to note that in the Bade group of West Chadic languages, the flap has undergone sound changes in Gashua Bade and Western Bade which are very similar to the sound changes reconstructed for the Masa group. As illustrated in (16), the Proto-Bade flap *r has undergone the change $*_{r}>*_{1}$ in Gashua Bade, but $*_{r}>*_{r}$ in Western Bade. The flap $*_{r}$ remains a flap in Ngizim. The Proto-Bade ${ }^{*} r$ persists as a trill in the three languages [Schuh 1981a, b; p.c.]. 
(16) Reflexes of Proto-Bade $*_{r}$ and ${ }^{*} r$

\begin{tabular}{|c|c|c|c|c|}
\hline $\begin{array}{l}\text { Proto-Bade } \\
*_{\Gamma}\end{array}$ & $\begin{array}{l}\text { Ngizim } \\
\text { ràvàk }\end{array}$ & $\begin{array}{l}\text { Gashua Bade } \\
\text { àlàv̀̀k }\end{array}$ & $\begin{array}{l}\text { Western Bade } \\
\text { àrvàkôn }\end{array}$ & 'skin' \\
\hline$*_{r}$ & màrií & mòlí & mòrôn & 'beard' \\
\hline$*_{r}$ & zàgór & ̀̀zgál & àzqว̀rôn & 'foot' \\
\hline$*_{\mathrm{r}}$ & bórb̀̀r & bárbàr & bórbòrán & 'dust' \\
\hline$*_{\mathrm{r}}$ & ákúrnà & ákúrnà & ákúrnân & 'gruel' \\
\hline$*_{\mathrm{r}}$ & wûrjí & wûrjí & wúrjí & 'scorpion \\
\hline
\end{tabular}

4.4. Historical Inferences. If the Masa group were a member of Biu-Mandara-B, it would follow that this group of languages would exhibit the phonological innovations characteristic of both Biu-Mandara and Biu-Mandara-B. As noted above, there are four well-attested sound changes which affected Proto-BM and Proto-BM-B. In this section, I argue that only one of these sound changes could have affected Proto-MG. I demonstrate that the other three sound changes which affected the Biu-Mandara languages are not the same sound changes as those which affected Proto-MG.

First, as previously discussed, Proto-BM and Proto-MG exhibit the sound change Proto-Chadic $* b>{ }^{*}$. The fact that the Masa group and Biu-Mandara share this sound change may indicate that the Masa group is a subgroup in Biu-Mandara. However, the change $* b>*_{v}$ has occurred independently elsewhere in the Chadic family. The Zaar, Ron, and Bade groups of West Chadic, for instance, independently underwent this change. In the case of the Ron group, there was apparently subsequent devoicing of the labial fricative. These sound changes are illustrated in (17) for Zaar of the Zaar group [Shimizu 1978], Fyer of the Ron group [Jungraithmayr 1968, 1970], and Ngizim of the Bade group [Schuh 1981a].

$\begin{array}{llll}\text { Proto-Chadic *b }>*^{*} \mathrm{v} \text { in West Chadic } & & \\ \text { Proto-Chadic } & \text { Zaar } & \text { Fyer } & \text { Ngizim } \\ \text { *bədi 'monkey' } & \text { vwùrì } & \text { fì̀r } & \text { vòjií } \\ \text { *barə 'to give' } & \text { vưrtu } & \text { fà } & \\ \text { *bən- 'hut, house' } & \text { vìn } & \text { fen } & \\ \text { *badə 'five' } & & & \text { vàad } \\ \text { *bəna 'to wash oneself' } & & & \text { vìyú }\end{array}$

The fact that this sound change has occurred independently in three separate groups indicates that this is a common change in the Chadic family. Thus, the fact that the Biu-Mandara and Masa group languages exhibit this change may be attributed to the prevalence of this change in the Chadic family.

Newman [1977b] proposes that the Proto-Chadic inventory of sibilants and laterals includes ${ }^{*} \mathrm{~s},{ }^{*} \mathrm{z},{ }^{*} \mathrm{~S}$, and ${ }^{*}$. As noted earlier, Proto-BM underwent the 
sound change Proto-Chadic $* S>$ Proto-BM * $*$ In other words, Proto-Chadic $* S$ merged with Proto-Chadic * in Proto-BM. In Proto-MG, however, Proto-Chadic *S merged with Proto-Chadic *s. As Newman [1977b] first noted, the merger of Proto-Chadic *S with Proto-Chadic *s provides strong evidence against classification of the Masa group as a subgroup of Biu-Mandara. It is not plausible that the merger of the Proto-Chadic ${ }^{*} S$ and $*$ characteristic of Biu-Mandara could subsequently be reversed in the Masa group, with the reflexes of Proto-Chadic ${ }^{*} S$ shifting to *s.

After the split of Proto-BM into its two subbranches, the change Proto-BM ${ }^{*} \mathrm{r}>$ *l affected Proto-BM-B. After Masa group split into its two subgroups, the sound change (Proto-Chadic ${ }^{*} r>$ ) Proto-Masa ${ }_{r}>{ }^{*}$ l applied to the languages of the northern subgroup. As a result, there are superficial similarities between cognates in the northern subgroup and Biu-Mandara-B, e.g., [kūlùf+nà] 'fish' in Masa and [kilif] in Musgu and [kilfi] in Gidar. Nonetheless, this sound change in the northern subgroup of Masa was a development independent of the sound change noted for Proto-BM-B.

In the last case to be considered, the sound change $*_{\mathrm{d}}>{ }^{*} \mathrm{r} / \mathrm{V}_{-} \mathrm{V}$ affected Proto-BM-B and the Proto-Masa group. In Proto-BM-B, this sound change followed the sound change Proto-BM ${ }^{*} \mathrm{r}>{ }^{*} \mathrm{l}$. As just noted, the sound change ${ }^{*} \mathrm{r}>$ ${ }^{*}$ l did not apply to Proto-MG. It follows that the sound change $*_{\mathrm{d}}>*_{\mathrm{r}} / \mathrm{V}_{-} \mathrm{V}$ could not have applied to Proto-BM-B and Proto-MG at the same point in time. If this sound change had applied to Proto-BM-B and Proto-MG at the same point in time, Proto-MG would necessarily exhibit the prior sound change of Proto-BM *r $>{ }^{*}$ l.

These sound changes and their relative chronologies are summarized in (18). On the left, note the two sound changes affecting Proto-BM after the breakup of Proto-Chadic: Proto-Chadic $* b>*_{v}$ and Proto-Chadic $* S>*$. After the split of Proto-BM, two changes affected Proto-BM-B: Proto-BM ${ }^{*} \mathrm{r}>{ }^{*} \mathrm{l}$ and Proto-BM ${ }^{*} \mathrm{~d}$ $>{ }^{*} \mathrm{r} / \mathrm{V}_{-} \mathrm{V}$. On the right, three sound changes affected the Proto-Masa group after the breakup of Proto-Chadic: Proto-Chadic $* b>*_{v}$, Proto-Chadic $* S>*^{*}$, and Proto-Chadic $* \mathrm{~d}>{ }^{*} \mathrm{r}$ (reconstructed as a trill) / V_V. Finally, after the Proto-Masa group split into the northern and southern subgroups, the northern subgroup underwent the change $*_{r}>* 1$.

In summary, there is one shared phonological innovation which could support the subclassification of the Masa group within Biu-Mandara: Proto-Chadic *b $>$ *v. The fact that the Masa group and Biu-Mandara exhibit this sound change does not, however, indicate that the Masa group should be subclassified in BiuMandara. Such a proposal would attribute considerable importance to a single sound change which has occurred independently in other languages of the Chadic family. Moreover, there are three additional sound changes reconstructed for Proto$\mathrm{BM}$ and Proto-BM-B which cannot be reconstructed for Proto-MG. 
(18) Relative chronologies of the sound changes of Biu-Mandara and the Masa group
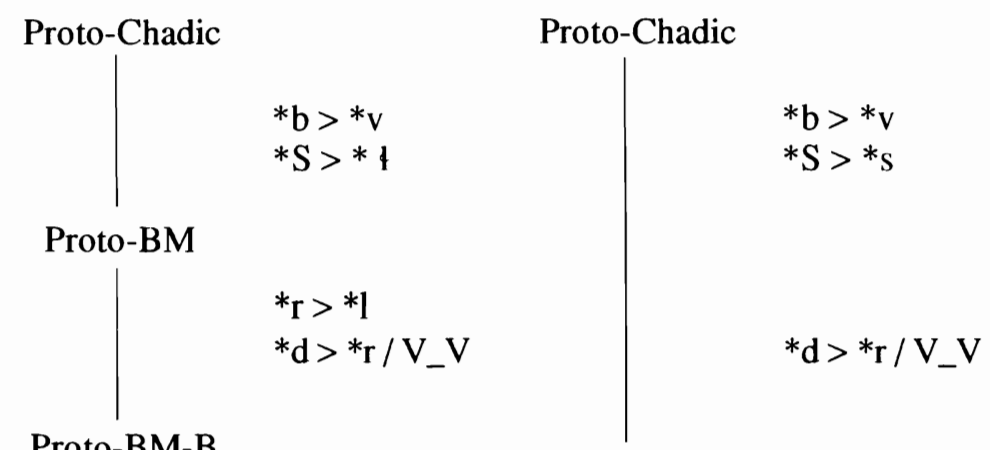

Proto-BM-B
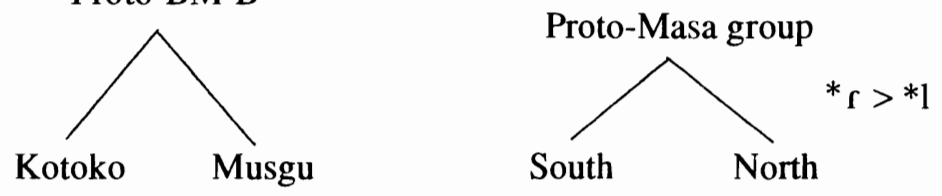

\section{Lexical Innovations}

The presence of shared lexical innovations provides strong positive evidence for the subclassification of languages. In this section, I present five lexical innovations characteristic of the Biu-Mandara branch as a whole and one innovation characteristic of the Biu-Mandara-B subbranch. In each case, the languages of the Masa group do not exhibit these lexical innovations.

5.1. Biu-Mandara innovations. There are three words reconstructed for ProtoChadic which are well attested in the West and East Chadic branches but absent in Biu-Mandara: Proto-Chadic *ba 'mouth', *ti 'to eat', and *badə 'five' [Newman 1977b]. The Biu-Mandara languages exhibit the innovations *ma 'mouth' and *zomə 'to eat' [Newman 1977b]. As for Proto-Chadic *badə 'five', the BiuMandara languages exhibit reflexes of a form which I provisionally reconstruct as Proto-BM * $3 ə m$ 'five'. In the case of each of these innovations, the Masa group exhibits a reflex of the Proto-Chadic form, not the Biu-Mandara innovation. The Proto-Chadic (PC) reconstructions and their reflexes in West and East Chadic and the Masa group as well as the Biu-Mandara innovations are illustrated in (19). 
(19) Biu-Mandara lexical innovations

\begin{tabular}{|c|c|c|c|c|c|}
\hline \multicolumn{2}{|c|}{ Proto-Chadic } & BM & Masa & West & East \\
\hline *ba & 'mouth' & $\begin{array}{l}\text { Mg ma } \\
\mathrm{G} \mathrm{ma} \\
\mathrm{Db} m a\end{array}$ & $\begin{array}{l}\mathrm{Z} \text { vun } \\
\mathrm{Mu} \text { vùn+nà }\end{array}$ & $\begin{array}{l}\text { Ha baakii } \\
\mathrm{Zr} \text { vi } \\
\mathrm{Mi} \text { vin }\end{array}$ & $\begin{array}{l}\text { D bii } \\
\text { So bo }\end{array}$ \\
\hline$*_{\mathrm{ti}}$ & 'to eat' & $\begin{array}{l}\mathrm{T} \text { zəmə } \\
\mathrm{Br} \text { səm } \\
\mathrm{Bu} \text { hum }\end{array}$ & $\begin{array}{l}\mathrm{Z} t i \\
\mathrm{Ma} t i\end{array}$ & $\begin{array}{ll}\mathrm{Ha} & c i \\
\mathrm{Ng} & t a \\
\mathrm{Kk} & \text { tu }\end{array}$ & $\begin{array}{l}\text { D tèè } \\
\text { Bi táyà }\end{array}$ \\
\hline *badə & 'five' & $\begin{array}{l}\text { Mg } \text { lim } \\
\text { Mt kam } \\
\text { Gl bəba }\end{array}$ & $\begin{array}{l}\mathrm{Z} \text { vàł } \\
\text { Ma vàt }\end{array}$ & $\begin{array}{ll}\mathrm{Kk} & \text { baadu } \\
\mathrm{Mi} & \text { vat } \\
\mathrm{Ng} & \text { vààd }\end{array}$ & $\begin{array}{l}\text { D beedy } \\
\text { Ke wiidiw }\end{array}$ \\
\hline
\end{tabular}

In addition, there are two forms which are widely attested in the Biu-Mandara branch but which do not occur in East or West Chadic. I provisionally reconstruct these Biu-Mandara innovations as Proto-BM *kur- 'urine' and *tuw- 'to weep', following Jungraithmayr and Ibriszimow [1994]. These innovations do not appear in the Masa group. The Biu-Mandara reconstructions and their reflexes as well as the unrelated forms found in the Masa group are presented in (20). Note that the Masa [tii] 'to weep' is reconstructed for the northern subgroup as *tir. As seen in the reconstructions in Appendix B, word-final [r] has been lost in the northern subgroup with compensatory lengthening of the preceding vowel.

(20) Biu-Mandara lexical innovations

$\begin{array}{llll}\text { Proto-BM } & \text { BM-A } & \text { BM-B } & \text { Masa } \\ \text { *kur- 'urine' } & \text { Dg kúrè } & \text { Y kóray } & \text { Mu súmúútrā } \\ & \text { Mt kùrày } & \text { G kúnne } & \text { P jàbūr } \\ & \text { Gs kunnay } & \text { Ko nkúne } & \\ \text { *tuw- 'to weep' } & \text { Gd tūna } & \text { Mg twa } & \text { Z si?i } \\ & \text { Gs tuway } & \text { Ko súwé } & \text { Ma tii } \\ & \text { Dg tàwá } & & \end{array}$

Finally, the BM-B languages exhibit the irregular sound change $*_{k}>*_{f}$ in Proto-Chadic *aku/akwa 'fire'. In BM-A and the Masa group, though, the irregular ${ }^{*} \mathrm{k}>{ }^{*} \mathrm{f}$ did not occur as seen in (21). The regular reflex of Proto-Chadic ${ }^{*} \mathrm{k}$ is Proto-MG ${ }^{*}$ h, e.g., Proto-Chadic *kədəm 'crocodile' corresponds to Proto-MG *hurum. Thus, Proto-MG *ku 'fire' does not exhibit the expected reflex of ProtoChadic ${ }^{*} \mathrm{k}$. It remains to be determined why Proto-MG ${ }^{*} \mathrm{ku}$ did not undergo the sound change Proto-Chadic ${ }^{*} \mathrm{k}>$ Proto-MG ${ }^{*} \mathrm{~h}$. 
(21) ${ }^{*} k>* f$ in Proto-Chadic *aku/akwa 'fire'

$\begin{array}{llll}\text { Proto-Chadic } & \text { BM-B } & \text { BM-A } & \text { Masa } \\ \text { *aku/akwa } & \text { Mg afu } & \text { Mt akwa } & \text { Ma kū+nā } \\ & \text { G affa } & \text { Gd gwun } & \text { Mb } a k k u+d a \\ & \text { Lo fu } & \text { Hi rwi } & \text { P kū }\end{array}$

As noted earlier, the presence of shared innovations provides positive evidence for subclassification. Six lexical innovations have been reconstructed for the BiuMandara languages. It is striking that the languages of the Masa group do not exhibit even one of the lexical innovations. The absence of these lexical innovations provides strong evidence against the subclassification of the Masa group in the Biu-Mandara branch of Chadic.

\section{A Morphological Innovation}

In this last section, I consider the innovation of the third person plural pronoun in Chadic. The three major branches of Chadic differ with respect to the shape of the third person plural pronoun. The West Chadic languages exhibit a reflex of the PC third person plural *sun [Kraft 1972, Newman 1980]. The northern subgroup of the Masa group exhibits the pronoun $*_{-z i}$, a reflex of PC *sun. In the southern subgroup of Masa, though, the innovation *na occurs. In the East Chadic languages, the third person plural can be reconstructed as *k- $n$, possibly originating from the PC plural determiner $*_{k}$ - and the $*_{n}$ plural [Schuh 1983a]. Finally, the Biu-Mandara languages exhibit the innovation *t-n [Kraft 1972]. These distinct pronouns are illustrated in (22).

(22) The third person plural pronoun in Chadic

$\begin{array}{lllll}\text { Proto-Chadic } & \text { West } & \text { Masa } & \text { BM } & \text { East } \\ \text { *sun 'they' } & \text { Ha suu } & \text { Ma nd+izi } & \text { Ga tənda } & \text { Mk +a } \\ & \text { Dw sup } & \text { Mu azi } & \text { Lo +tən } & \text { So +gin } \\ & \text { Gj si } & \text { P ku+na } & \text { Ba tə̀ } & \text { Si gə } \\ & \text { Ge sundi } & \text { Z ta+na } & \text { M dar } & \end{array}$

Note that the Biu-Mandara innovation *t-n cannot be reconstructed for the Masa group. The northern subgroup of the Masa group exhibits a reflex of PC *sun whereas the southern subgroup exhibits the innovation *na. The absence of this innovation provides further evidence against the classification of the Masa group in Biu-Mandara. 


\section{Conclusion}

In summary, there is no conclusive evidence from shared innovations which supports the subclassification of the Masa group of languages in Biu-Mandara. The only shared phonological innovation which could indicate a close genetic relation between Biu-Mandara and the Masa group is the sound change Proto-Chadic ${ }^{*} \mathrm{~b}>>^{*} \mathrm{v}$. However, this is a sound change which has occurred independently in other parts of the Chadic family. Moreover, there are three other phonological changes attested in Biu-Mandara which cannot be reconstructed for the Masa group. In addition, the Masa group does not exhibit the lexical and morphological innovations characteristic of Biu-Mandara and Biu-Mandara-B. Thus, I propose that the Masa group be classified as a separate, fourth branch of Chadic as first proposed by Newman [1977b]. 


\section{Appendix A}

\section{Abbreviations}

The following abbreviations are used in this paper. The classification of each language and sources for the data cited are also indicated. Newman [1977b] is abbreviated as 'N 1977', Jungraithmayr and Ibriszimow [1994 ]as 'J\&I 1994.'

\begin{tabular}{|c|c|c|c|}
\hline $\mathrm{Ba}$ & Bacama & BM, A, Bata group & Kraft 1972 \\
\hline $\mathrm{Bi}$ & Birgit & East, B, Dangla group & J\&I 1994 \\
\hline $\mathrm{Br}$ & Bura & BM, A, Bura group & Kraft 1981 \\
\hline $\mathrm{Bu}$ & Buduma & BM, B, Kotoko group & Lukas 1939 \\
\hline $\mathrm{D}$ & Dangla & East, B, Dangla group & Fédry 1971, N 1977 \\
\hline $\mathrm{Db}$ & Daba & BM, A, Daba group & N 1977 \\
\hline $\mathrm{Dg}$ & Dghwede & $\mathrm{BM}, \mathrm{A}, \mathrm{Mandara}$ group & J\&I 1994 \\
\hline Dw & Dwot & West, B, Saya group & Kraft 1972 \\
\hline $\mathrm{G}$ & Gidar & BM, B, Gidar group & Schuh n.d. \\
\hline $\mathrm{Ga}$ & Gabin & BM, A, Tera group & Kraft 1972 \\
\hline $\mathrm{Gd}$ & Gude & $\mathrm{BM}, \mathrm{A}$, Bacama group & N 1977, J\&I 1994 \\
\hline $\mathrm{Ge}$ & Geruma & West, A, Bole group & Schuh 1978 \\
\hline $\mathrm{Gj}$ & Geji & West, B, Saya & Kraft 1972 \\
\hline $\mathrm{Gl}$ & Glavda & BM, A, Matakam group & Rapp and Mühle 1969 \\
\hline Gs & Gisiga & $\mathrm{BM}, \mathrm{A}$, Matakam group & Lukas 1970, J\&I 1994 \\
\hline $\mathrm{H}$ & Hede & Masa group & Noss 1990 \\
\hline $\mathrm{Ha}$ & Hausa & West, A, Hausa group & N 1977 \\
\hline $\mathrm{Hi}$ & Higi & BM, A, Higi group & N 1977, Kraft 1981 \\
\hline $\mathbf{J}$ & Jara & $\mathrm{BM}, \mathrm{A}$, Tera group & N 1977 \\
\hline $\mathrm{Ke}$ & Kera & East, A, Kera group & N 1977 \\
\hline $\mathrm{Kk}$ & Kanakuru & West, A, Bole group & N 1977 \\
\hline Ko & Kotoko & BM, B, Kotoko group & J\&I 1994 \\
\hline Lng & Lamang & $\mathrm{BM}, \mathrm{A}$, Mandara group & Wolff 1983 \\
\hline Lo & Logone & BM, B, Kotoko group & Lukas 1936 \\
\hline M & Margi & $\mathrm{BM}, \mathrm{A}$, Bura group & N 1977 \\
\hline Ma & Masa & Masa group & Caïtucoli 1983 \\
\hline $\mathrm{Mb}$ & Marba & Masa group & Franco 1970 , Price 1968 \\
\hline $\mathrm{Mg}$ & Musgu & BM, B, Kotoko group & Lukas 1941 \\
\hline $\mathrm{Mi}$ & Miya & West, A, Bole group & Schuh 1995 \\
\hline $\mathrm{Mk}$ & Mokilko & East, B, Mukulu group & Jungraithmayr 1990 \\
\hline $\mathrm{Mn}$ & Mandara & $\mathrm{BM}, \mathrm{A}$, Mandara group & N 1977 \\
\hline Mt & Matakam & BM, A, Matakam group & N 1977, Kraft 1981, J\&I 1994 \\
\hline $\mathrm{Mu}$ & Musey & Masa group & Shryock 1995 \\
\hline $\mathrm{N}$ & Ngide & Masa group & Noss 1990 \\
\hline $\mathrm{Ng}$ & Ngizim & West, B, Bade group & Schuh 1981a \\
\hline
\end{tabular}




$\begin{array}{llll}\text { P } & \text { Peve } & \text { Masa group } & \text { Cooper 1984, Hufnagel } 1986 \\ \text { Pd } & \text { Paduko } & \text { BM, A, Mandara group } & \text { N } 1977 \\ \text { Si } & \text { Sibine } & \text { East, A, Somrai group } & \text { Jungraithmayr 1978b } \\ \text { So } & \text { Somrai } & \text { East, A, Somrai group } & \text { N } 1977 \\ \text { T } & \text { Tera } & \text { BM, A, Tera group } & \text { N } 1977 \\ \text { Y } & \text { Yedin } & \text { BM, B, Kotoko group } & \text { J\&I 1994 } \\ \text { Z } & \text { Zime } & \text { Masa group } & \text { Hufnagel 1986, Kraft 1981 } \\ \text { Zr } & \text { Zaar } & \text { West, B, Zaar group } & \text { N } 1977\end{array}$

\section{Appendix B}

\section{The Lexicon of Proto-Masa Group}

This appendix contains a list of 204 words reconstructed for Proto-Masa group with the data supporting these reconstructions. The data cited below is taken from the sources noted in Appendix A for the respective languages. In the case of Peve, ' $P$ ' designates data from Cooper [1984], and 'P2' data from Hufnagel [1986]. Likewise, ' $Z$ ' designates Hufnagel [1986], and 'Z2' Kraft [1981].

The consonantal inventory outlined in (1) is reconstructed for Proto-Masa group. In addition, five vowels are reconstructed: $*_{\mathrm{i}},{ }^{*} \mathrm{e},{ }^{*} \mathrm{a},{ }^{*} \mathrm{o},{ }^{*} \mathrm{u}$. Tone has not been reconstructed. The tone patterns of verbs are not indicated because tone has a grammatical function in these languages, indicating the aspect of the verb (cf. [Jungraithmayr 1978a, Caiitucoli 1983]). For the nouns, however, tone is lexical; consequently, the tone of the nouns has been indicated if transcribed in the original source. Finally, in Masa, Musey, and Marba, the grammatical gender of nouns is explicitly marked by an enclitic: /na/ for masculine nouns, /da/ for feminine nouns.

(1) Consonantal inventory of Proto-MG

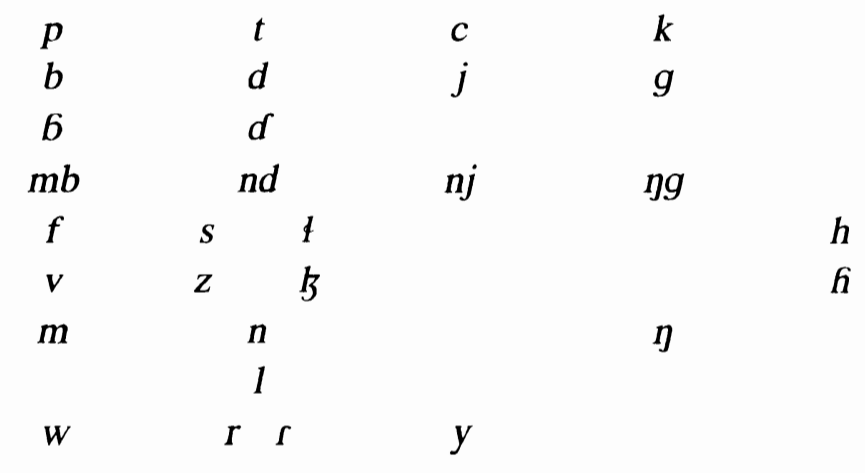


1. to accompany: *tin

Ms tin, $\mathrm{Mb}$ tin, $\mathrm{P}$ cin, $\mathrm{H}$ tin

2. antelope: *zar

Ms zàà+nà, Mb azar+a, $\mathrm{P}$ zār, $\mathrm{H}$ zar

3. ashes: *but

Ms bùt+nà, Mb but+na, $\mathrm{P}$ būt, $\mathrm{H}$ butu, $\mathrm{N}$ pùtù, $\mathrm{Z}$ bud

4. to ask: *j-p

Ma jop, Ms jop, Mb jop, P2 ca6 la, H cap

5. arm, hand: *6a

Ma 6ăm+nā, Mb abo+na, P bā, H ba, N bá, Z ba

6. to awake: *3-

Ma łii, Ms łit, Mb łi, $\mathrm{H}$ ła?

7. bark, peal: *b-1-k

Ma būlōk+nā, Ms bōlók+nā, Mb bloh+a, P bə̄lē?, H bəle?

8. bat: *babay

Ma bàybày+nà, Ms bàbày+nà, $M b$ abibey+na, $P$ bābāy, $H$ bəbay

9. bean: *rit

Ms līt+nà, $\mathrm{Mb}$ alit+na, $\mathrm{P}$ réd, $\mathrm{H}$ rede

10. bee, honey: *y-m

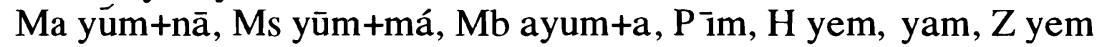

11. beer: *sum

Ms sūm+mà, Mb sum+a, $P$ sūm, $H$ sum

12. to belch: *gil

Ma gił, Ms git, Mb gil, $\mathrm{P} 2$ gil, $\mathrm{H}$ giti?, $\mathrm{Z}$ giti

13. to bite: *et

Ms et, $\mathrm{Mb}$ et, $\mathrm{P} 2$ et, $\mathrm{H}$ et, $\mathrm{N}$ ete, $\mathrm{Z}$ ede

14. black: *wura

Ma wūrā, Ms wár, Mb ura+da, P2 ura?, H ura?, Z2 wura

15. blacksmith, hammer: *caf

Ma cāf+nā, Ms cāf+fā, H caf

16. blow: *fo

$\mathrm{Ma}$ fo, Ms fo, Mb fo, $\mathrm{P}$ fo?, $\mathrm{H}$ fo?, $\mathrm{Z}$ fo?o

17. blood: *vuzur

Ma bùzùù+nà, $M s$ bùzùù+nà, $M b$ buzu+na, $P$ vūsū, $H$ vursu, $Z$ vursu

18. body: *tu

Ma tūù+nà, Ms tá+rā, Mb ta+da, $\mathrm{P}$ tū, $\mathrm{H}$ tu, $\mathrm{Z}$ tu

19. to boil: *zar

Ma zal, Ms zal, Mb zal, P2 sar, H sar, Z2 zar 
20. bone: *sok

Ma zòk+nā, Ms sōk+nà, $M b$ assoh+a, $P$ ùsō, $H$ uso, $Z$ iseu

21. brain: *to?on

Ma tōđōn+nā, Ms tōtō?ōn+nā, Mb tohon+da, P tū?óm wā, H te?em wa, Z2 to?om

22. to break: ${ }^{*} \mathrm{k}-\mathrm{s}$

Ma kus, Ms kus, Mb kus, P kəy, $\mathrm{H}$ kas, $\mathrm{Z}$ kas

23. breast: *po

Ma pō+nà, Ms pō+nà, Mb appo+na, $\mathrm{P}$ pā?, $\mathrm{H}$ pa?, Z pa

24. to breathe: ${ }^{*} \mathrm{~m}-\mathrm{s}-\mathrm{k}$

Ms mūzūk, Mb muzuk, P2 mai, $\mathrm{H}$ mas

25. broom: *samat

Ms sámát+nā, $\mathrm{Mb}$ assumat+na, $\mathrm{P}$ sāmdà

26. to carve: *cet

Ma ced, Ms cet, $\mathrm{Mb}$ cet, $\mathrm{P}$ ced, $\mathrm{H}$ ced, $\mathrm{N}$ cede, $\mathrm{Z}$ ced

27. charcoal: $*_{v-n}$

Ma vèy+nà, $P$ vōn, $L$ ?ávàn

28. chin: *d-m

Ma dǔm+nā, Ms dǔm+mā, Mb dudum+a, $\mathrm{P}$ jìm, $\mathrm{H}$ dim, $\mathrm{Z} 2$ dum

29. co-wife: *h-n

Ms hēnē+rà, $\mathrm{H}$ hin

30. cold: *hep

Ms hēp, Mb ahep, $\mathrm{P}$ he6, $\mathrm{H}$ he6

31. to come: *mb-

Ma mba, Ms mba, Mb mba, P mbu, $\mathrm{H}$ mbu, Z mba

32. to cough: ${ }^{*}$ of

Ma of, Ms of, Mb hoł, $\mathrm{P}$ of, $\mathrm{H}$ uło?, $\mathrm{Z}$ of

33. crocodile: *hurum

Ma hūrūm+nā, Ms hūrùm+mà, Mb hurum+a, $\mathrm{P}$ hūrūm, $\mathrm{H}$ hurum, $\mathrm{N}$ hūrūm, Z hurum

34. to cultivate: *zum

Ma zum, Ms zum, Mb zum, $\mathrm{H}$ zum

35. to dance: *ndur

Ma nul, $\mathrm{H}$ nduru

36. darkness: *nduvun

Ma jùfūn+nā, Ms ndùvún+dā, Mb nduvun+da, $\mathrm{H}$ ndufun, $\mathrm{Z} 2$ ndufun

37. death, funeral: *mat

Ma mìt+nà, Ms māt+nà, Mb mat+na, $\mathrm{P}$ māt, $\mathrm{H}$ mata 
38. dew: *mb-d-

Ma māđuít+nā, Ms mbàdàgítnā, Mb mbadi+da, $\mathrm{P}$ mbàdà, $\mathrm{H}$ mbəda,

$\mathrm{Z} 2$ mida

39. to die: ${ }^{*} \mathrm{~m}-\mathrm{t}$

Ma mit, Ms mit, Mb mit, $\mathrm{P}$ mat, $\mathrm{H}$ mat, $\mathrm{Z}$ mat

40. to displace: $* \mathrm{j}-\mathrm{k}$

Ma jok, Ms jok 'move', Mb jok, $\mathrm{H}$ jik

41. to do: *ri See 'time', 'place'

Ma li, Ms li, Mb le, P ri, $\mathrm{H}$ re

42. $\operatorname{dog}: * d-$

Ma dīìnā, Ms đìinā, Mb adì+da, $P$ dā, $H$ əda, $N$ ādēè, $Z$ aida

43. to drink: *ci

Ma ci, Ms ci, Mbce, P2 ce, $\mathrm{H}$ ce, $Z$ ce

44. ear: *hum

Ma hùm+nà, $\mathrm{Ms}$ hūm+bà, $\mathrm{Mb}$ hum+ba, $\mathrm{P}$ hūm, $\mathrm{H}$ hum, $\mathrm{N}$ húm, $\mathrm{Z}$ hum

45. to eat: *ti

Ma ti, Ms ti, Mb te, $\mathrm{P}$ ti, $\mathrm{H}$ ti, $\mathrm{N}$ ti, $\mathrm{Z}$ ti

46. to eat meat: ${ }^{*} \mathrm{k}-\mathrm{m}$

Ms kom, $\mathrm{P}$ kam, $\mathrm{H}$ kam

47. egg: *se

Ma zè+nà, Ms sē+nà, Mb asse+na, $\mathrm{P} \int \bar{e}$ ?, $\mathrm{H}$ se?, $\mathrm{N}$ Je?, Z se?e

48. to enter: ${ }^{*} \mathrm{kal}$

Ma kal, Ms kal, Mb kal, P2 kal, H kal

49. excrement: *sot

Ma sūđáy+nā, Ms sōt+nà, $\mathrm{P}$ sód, $\mathrm{H}$ sod, $\mathrm{Z}$ sođo

50. to extract: *pat

Ma pat, Ms pat, Mb pat, $\mathrm{P}$ pat, $\mathrm{H}$ pat

51. eye: *ir

Ma $\widehat{1} 1+$ rà, Ms î́1+rà, $M b$ irta, $P \overline{1}, H$ ir, $N$ ér, $Z$ ir

52. to fall: *nd-

Ms ndi, $\mathrm{Mb}$ nde, $\mathrm{P}$ ndie, $\mathrm{H}$ nde, $\mathrm{Z} 2$ nde

53. father: *b-

Ma búm+nā, Ms bú+nā, Mb abu+na, $\mathrm{P}$ bà, $\mathrm{H}$ əba, ba, Z2 buba

54. feather: ${ }^{*} \mathrm{z}-\mathrm{m}$

Ma bìmìt, Ms bjīmīt+tā, Mb timit+a, $\mathrm{P}$ lām, $\mathrm{P} 2$ lam, $\mathrm{H}$ lam

55. field: *sine

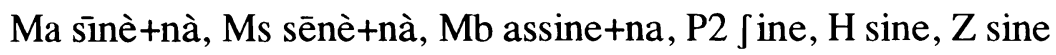

56. field rat: *njuk

Ms njùk+yà, $\mathrm{Mb}$ anjuh+a, $\mathrm{P} 2$ njuk, $\mathrm{H}$ njuk, $\mathrm{Z}$ njuku 
57. fig tree: *turum

Ms tùlúm+nā, $M b$ tulum+a, $\mathrm{P}$ tūrúm

58. fire: ${ }^{*} \mathrm{ku}$

Ma kū+nā, Ms kū+rà, Mb akku+da, P kū, H ku, Z ku

59. fish: ${ }^{*} \mathrm{k}-\mathrm{rf}$ -

Ma kūlùf+nà, Ms kūlùf+fà, Mb kluf+a, $P$ kīēfè, $H$ kerfe, $N$ kérfé, $Z$ kife?e

60. five: *val

Ma vàł, $M s$ vàł, $M b$ vał, $P$ vāł, $H$ vał, $N$ vàł, $Z$ vał

61. flour: *fut

Ms fūt+tà, Mb affut+a, P fūt, P2 fur, $\mathrm{H}$ fut, $\mathrm{Z} 2$ fut

62. flute: $* d-f$

Ma díf+nā, Ms díf+fā, Mb adif +a, $\mathrm{P}$ dūp, $\mathrm{H}$ duf

63. fly: *raw

Ma rāw+nā, Mb aro+na, $P$ rīrēw, $H$ rirew, $Z$ larau

64. foot, leg: *sem

Ma sēm, Ms sēm+má, Mb assem+a, P fēm, H sam, L sém, N sám, Z sem

65. to forge: * ${ }^{*} \mathrm{i}$

Ma łi, Ms łi, Mb ze, $\mathrm{P}$ łam, $\mathrm{H}$ łe

66. fork, forked stick: *garak

Ms gàràk+nà, Mb grak+a, L garak

67. four: *fidi

Ma fīdì, Ms fídì, Mb fidi, $P$ fádîn, $H$ fid î, $N$ fád ì, $Z$ fid i

68. front: ${ }^{*} \mathrm{v}-\mathrm{k}$

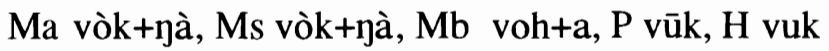

69. to fry: *haw

Ma haw, Ms haw, Mb haw, $\mathrm{P}$ haw, $\mathrm{H}$ haw, $\mathrm{Z}$ hau

70. girl: *way

Ms wăy+rā, P wāy, H wai

71. to give birth: *vut

Ma vư, $M s$ vut, $M b$ vut, $P$ fàrà?, $H$ vórá?, $Z$ vra?a

72. to go: $*_{\mathrm{t}-}$

Ma tud, Ms tut, $\mathrm{P}$ ta, $\mathrm{H}$ ta, $\mathrm{Z}$ ta

73. goat: *hu

Ma hù̀nà, Ms hù+nà, Mb ahu+na, $\mathrm{P}$ hū, $\mathrm{H}$ uhu, $\mathrm{Z}$ afu

74. granary: ${ }^{*} \mathrm{z}-\eta$

Ms zày+nà 'shelter', Mb azãy+a 'shelter', $\mathrm{P} 2$ zəna, $\mathrm{H}$ səna, $\mathrm{Z}$ zina

75. grass: *-s-

Ma wūs+nā, Ms úùzú+nā, Mb assu+na, P2 za, H əsa 
76. grave: *us

Ma wūs+nā, Ms ūs+sà, Mb assu+da, $\mathrm{H}$ wa us

77. to grill: *war

Ms war, $\mathrm{P}$ wor, $\mathrm{H}$ war

78. hair: *ngusa

Ms ngús+sã̃, $\mathrm{P}$ sấ wā, $\mathrm{H}$ ggisã wa, $\mathrm{Z}$ ggisa wa

79. hare: ${ }^{*} \mathrm{v}-\mathrm{t}$

Ma vèt+nā, Ms vèt+tà, $M b$ avvivet+a, $P$ fád īi,$H$ fiti, $Z$ viti

80. harmattan: *kut

Ms kūt+nā, Mb akkukut+na, P kūt, $\mathrm{H}$ kut

81. to hatch: *ef

Ma el, Ms et, $\mathrm{P}$ iet, $\mathrm{H}$ ef

82. to hear, understand: *hum

Ma hum, Ms hum, Mb hum, $\mathrm{P}$ hum, $\mathrm{H}$ hum, $\mathrm{N}$ hum, $\mathrm{Z} 2$ hum

83. heart: *g-1-s

Ma glês+nā, Ms gílís 'kidney', P gala vəsə

84. hedgehog: *cem

Ma cèmcèm+nà, Ms cêmcém+mā, $M b$ cicem+a, $P$ cēcīmè, $H$ cancime

85. to help: *njin

Ms njun, Mb njun, $\mathrm{P}$ jin, $\mathrm{H}$ jin

86. to hit: ${ }^{*} \mathrm{p}-\mathrm{m}$

Ms pon, $\mathrm{P}$ pum, $\mathrm{H}$ pum

87. to hit, kill: ${ }^{*} \mathrm{ci}$

Ma ci, Ms ci, Mb ci, $\mathrm{P}$ ci, $\mathrm{H}$ ci, $\mathrm{N}$ ci, $\mathrm{Z}$ ci

88. hole: ${ }^{*} \mathrm{z}-\mathrm{r}$

Ma zùl+lā, Ms zùl+là, Mb zul+a, $P$ zōrā, $H$ zəra, $Z$ zra

89. horn: *mek

Ma mīyōk+nā, Ms mēk+kā, P mīēk, L méké, Z mek

90. hunger: *me

Ma máy+nā, Ms māy+rá, Mb mey+da, P mīēe, H me?e, Z2 me

91. hunt: *ram

Ms lām+bà, Mb alam+ba, $\mathrm{P}$ rāy, $\mathrm{H}$ rạ

92. hut, compound: ${ }^{*} \mathrm{z}-$

Ma zìì +nà, Ms zì +nà, Mb azi+da, $\mathrm{P}$ só, $\mathrm{P} 2$ zəba, $\mathrm{H}$ za, $\mathrm{Z}$ za

93. intestines: ${ }^{*} \mathrm{r}-\mathrm{w}-\mathrm{t}$

Ma rwāt+nā, Mb arruwat+na, $P$ rāwti, $H$ raw

94. knee: *gif

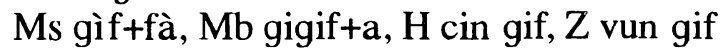


95. to know, see: *wi

Ma wi, Ms wi, Mb we, $\mathrm{P}$ wa?, $\mathrm{H}$ ye, $\mathrm{Z}$ we

96. land, uninhabited and uncultivated: *fur

Ms fül+là, $\mathrm{H}$ fur

97. larynx, voice: *hor

Ms hòó+nā, Mb hor+ã, $\mathrm{P}$ hòr, $\mathrm{H}$ hor

98. leaf, foliage: *

Ms łáp+mà, Mb ałap+ma 'shrub, bush', P tāp, H łapa, Z ła6

99. to leave, forbid: *hin

Ma hin, Ms hin, Mb hin, $\mathrm{P}$ hin

100. left: *gur

Ms gùl, $\mathrm{P} 2$ gur, $\mathrm{H} 2$ gura, $\mathrm{Z}$ gur

101. to lift: * $4 \mathrm{i}$

Ma ti, Ms di, Mb te, $\mathrm{P}$ tie

102. liver: *duk

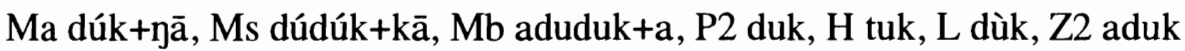

103. to lose, disappear: *vid

Ms vit, $\mathrm{Mb}$ vit, $\mathrm{P}$ fid, $\mathrm{H}$ vid

104. mahogany (Khaya senegalensis): ${ }^{*} \mathrm{~g}-\mathrm{m}$

Ma gám+nā, Ms gám+mā, L guma, Z2 guma

105. man, husband: ${ }^{*}$ nj-f

Ma jŭf+nā, Ms njǔf+fã̃, Mb njuf+a, P njī, H nji , N njìf, Z nji

106. mat: * zat

Ma ł̧ăt+nā, Ms łăt+nā, Mb łat+na, P lā?, H la?a

107. to mature: *cen

Ms jen, $\mathrm{P}$ cen

108. meat, flesh: *liw

Ma łīw+nā, Ms łīw+nā, Mb łiu+na, $P$ łí éw, $H$ łew, $Z$ łeu

109. melon: *b-

Ma búū+nā, Ms bú+nā, Mb bubu+da, P2 bo?, H po?, Z2 bo?o

110. milk: *mbir

Ma mbíī +rā, Ms mbì̀̀ +rà, Mb ambi+ra, P mbīr, H mbir, Z2 mbir

111. to mix: *lum

Ms łum, P lum, H lum

112. monkey: *vir

Ma vìi +rà, Ms vìì +rà, $M b$ vi+ra, $P$ vīr, $H$ vir, $Z$ vir

113. moon: *tir

Ma tīl+tā, Ms tīlã̃, Mb tilla, $\mathrm{P}$ cēr, $\mathrm{H}$ tér, $\mathrm{Z}$ ter 
114. mortar: $*_{\mathrm{zu}}$

Ma zùù+nà, Ms zùzú+nā, $\mathrm{Mb}$ zuzo+da, $\mathrm{P} 2$ zu?, $\mathrm{H}$ zu?u

115. mouth: *vun

$M a$ vùn+nà, $M s$ vùn+nà, $M b$ vun+a, $P$ vūn, $H$ vùn, $Z$ vin

116. mud, clay: *rubu

Ms lūbú+nā, Mb lubu+na, $\mathrm{P}$ ràbà, $\mathrm{P} 2$ rub, $\mathrm{H}$ rúbú, $\mathrm{Z}$ lubu

117. mud: *dorbo

Ms dòròfóp+mā, Mb dorbop+ma, $\mathrm{H}$ dōrbō, Z2 dorbo

118. mushroom: *bik

Ms bík+kā, Mb abigi+da, P bīk, H bik

119. name: *sem

Ma sēm+nā, Ms sēm+má, Mb simi+na, P Jēm, H sam, N sám, Z sem

120. navel: *fuk

Ms fūk+kā, Mb uf+a, P fú, H úfú, Z2 afuk

121. nose: ${ }^{*} \operatorname{cin}$

$M a$ cìn+nà, $M s$ cīn+nà, $M b$ acin+a, $P$ cīn, $H$ cín, $Z$ cin

122. to obtain: $* \mathrm{fi}$

Ma fi trouver, $\mathrm{Ms} \mathrm{fi}, \mathrm{Mb}$ fe, $\mathrm{P}$ fie, $\mathrm{H}$ fe, $\mathrm{Z}$ fe

123. to offer a sacrifice: $*$ bi vun

Ms bi vùn, $P$ bie vūn, $H$ be vun

124. oil, grease, fat: *mbur

Ma mūl+lā, Ms mbùl+lã, Mb mbul+a, $\mathrm{P}$ mbúr, $\mathrm{H}$ mbur, $\mathrm{N}$ mbúr, $\mathrm{Z}$ mbur

125. okra: *zor-

Ms łòònò+rà, $\mathrm{Mb}$ zulo+da, $\mathrm{P}$ jōr, $\mathrm{H}$ gor, $\mathrm{Z}$ gor

126. penis: $*_{\text {diw }}$

Ms dīi +rā, Mb diw+da, P2 diu, H diw

127. people: *su

Ms sūū, Mb suma+na, $\mathrm{H}$ suno, $\mathrm{L}$ sundo

128. person: *s-

Ma sā+nà, Ms sā+nà, Mb sa+na, $P$ sù, $H$ su, $N$ sū, $Z$ su

129. place: $*_{r i}$

Ma līínnā, Ms Tìn+nā, P rī, H ri, Z li

130. placenta: *tu?om

Ms tô?òm+mà, $\mathrm{Mb}$ atohom+a, $\mathrm{P}$ tū?óm, $\mathrm{L}$ tu?om

131. to play: * riu

Ma liu, Ms luu, Mb lu, $\mathrm{P} 2$ ru, $\mathrm{H}$ riu, $\mathrm{N}$ riu 'to dance', $\mathrm{Z}$ liu

132. pus: ${ }^{*}--$

Ms lōō+rā, P rīw, H rirew 
133. to put: *tin

Ma tun, Ms tin, tun, $\mathrm{Mb}$ tin, $\mathrm{P}$ cin, $\mathrm{H}$ tin, $\mathrm{Z}$ tin

134. to rain: *si

Ma si, Ms si, Mb se, P Je, L sé

135. rainy seaon: *ndor

Ms ndòl+là, Mb andol+a, $\mathrm{P}$ ndór, $\mathrm{H}$ ndor, $\mathrm{Z} 2$ ndor

136. to recieve: ${ }^{*} \mathrm{fi}$

Ma vi, $\mathrm{Ms}$ vi, $\mathrm{Mb}$ ve, $\mathrm{P}$ vie, $\mathrm{H}$ fe

137. to recline: *b-r

Ma bur, Ms bur, Mb bur, $\mathrm{P}$ par, $\mathrm{H}$ bar, $\mathrm{Z}$ bar

138. red: *lew

Ma łāw, Ms łāw, Mb łew, $\mathrm{P}$ lí éw, $\mathrm{H}$ ł̧eo, Z2 łeo

139. to return: *hom

Ms hoy, Mb hulon, $\mathrm{H}$ hom, $\mathrm{Z}$ hom

140. rhinoceros: *gay

Ma gáy+nā, Ms gày+rà, P gāī?, H gay, L gə?ì

141. to ripen: *ne

Ms ne, $M b$ ne, $P$ nie, $H$ ne, $Z$ ne?e

142. road, path: *vot

Ms vót+tā, Mb lovot+a, $P$ vārì,$H$ vārī,$N$ fààrì, $Z 2$ vari

143. to roast: * ${ }^{*}$ cuf

Ma cuf, Ms cuf, Mb cuf, $\mathrm{P}$ cu, $\mathrm{H}$ cu?u, $\mathrm{Z}$ cu

144. rooster: *golok

Ms gògòlók+nā, $P$ gùlòk, $H$ gùlòk

145. root: *s-r

Ma súdāy+nā, Ms sárí+nā, Mb sidey+na, L sér, Z seđ

146. rope: *zew

Ms zěw+nā, Mb zyeu+na, P Jèw, $H$ zèu, $Z$ zeu

147. roselle (hibiscus Sabdarifla): *łembe

Ma łém+nā, Ms łém+mā, Mb ałem+a, $P$ łzèb, $H$ łebe, $Z$ lebe

148. saliva: *ne

Ma nēēnē+nā, L ne?e

149. salt: *vu

Ms vùvú+nā, $P$ vū, $H$ úvù, $Z 2$ avu

150. sand: *net

Ma jèł+nā, Ms ngěł+lã̃, Mb yeł+a, $P$ nyēł, $H$ néłē, $Z$ ngeł

151. sauce: ${ }^{*}$ mbar

Ms mbàlá+rā, Mb ambla+da, P mbár, H mbár, Z mbar 
152. to scratch: *hurok

Ms horok 'to plow, farm', P hurok, H hurok

153. seed: *ir

Ms î́t+rà, $\mathrm{P} \overline{1}$

154. to send: *s-n

Ma sun, Ms sun, Mb sun, $P \int i n, H \sin , N \sin , Z$ sin

155. seven: *sida

Ma sīdíyā, Ms kīđīsíyā, Mb kidisya, P Jéđā? , H séđá, N seđa?, Z2 seda

156. to shake: *gasak

Ma gas, Mb gas, P2 gəzak, L gəsàk

157. sheep: *time

Ms tímí+rā, Mb timi+da, $P$ cimé, $H$ tīmé, $Z$ time

158. to shine, flash: *wile

Ms welet, Mb wile+da, $\mathrm{P}$ wudi, $\mathrm{H}$ wuli, $\mathrm{L}$ wile?e

159. shoulder, upper arm: *bike

Ms bìk +rà, Mb bik+a, $\mathrm{P}$ bì kè $6 \bar{a}, \mathrm{Z} 2$ wa bike ba

160. side, rib: *hay

Ma hày+nà, Ms hāy+rà 'stomach', Mb hay+da 'stomach', P hāi? 'beside',

$\mathrm{H}$ hai

161. six: *kargi

Ma kārgīyā, Ms kārgīyá, Mb karagaya, $\mathrm{P}$ kánkīi, $\mathrm{H}$ kángī, $\mathrm{H}$ kángì,

Z2 kandi

162. sleep: *sen

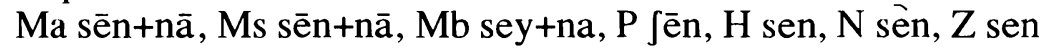

163. small: ${ }^{*} \mathrm{~g}-$

Ma gòr, $\mathrm{Ms}$ gòr, $\mathrm{Mb}$ gugor, $\mathrm{H}$ ga?, $\mathrm{Z} 2$ ga?a

164. spear: *sap

Ms sāp+pā, Mb assap+a, P sā6, H sābā, Z asa6a

165. spirit: *ful

Ma fúl+lā, Ms fūl+lẫ, P ífràyā , H, Z2 afi 'sky'

166. spirit, shadow: *ng-s

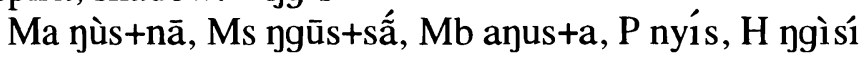

167. to squeeze: ${ }^{*} \mathrm{em}$

$\mathrm{Ms}$ em, $\mathrm{Mb}$ em, $\mathrm{P}$ iem, $\mathrm{H}$ em

168. to stand up: *cor

Ma col, Ms col, Mb col, P car, H car, Z car

169. star: *ciw

Ms cîwcíw+rā, Mb ciciw+da, $P$ cì cīw, $H$ ìcīu, $Z 2$ ciciu 
170. to steal: *kur

Ma kul, Ms kul, Mb kul, P kəy, H kir, Z kir

171. stone: *goy

Ms gòy+rà, P2 goi?, H gwoi?i, N kwòi, Z2 goy

172. story: *nd-n

Ms njùnjùn+dà, $\mathrm{Mb}$ jujun+da, $\mathrm{P}$ njì $\mathrm{n}, \mathrm{H}$ ndin, $\mathrm{Z}$ ndindin

173. to strike: *p-m

Ms poy, $\mathrm{P}$ pum, $\mathrm{H}$ pum

174. to suck: *sop

Ms sop, Mb sop, P so6, H sobo, Z so6

175. sun: *fat

Ma fàt+nà, $M s$ fāt+tà, $M b$ affat+a, $P$ vòtà, $H$ fútá, $Z$ fa da

176. sweat: ${ }^{*} \mathrm{z}$-mb-r

Ms zàmál+lã̃, Mb zumal+a, $\mathrm{P}$ sùmbùr, $\mathrm{L}$ sùmbùr

177. to swim: *lus

Ms lus, $\mathrm{P}$ lus, $\mathrm{H}$ lus

178. tail: ${ }^{*} \mathrm{c}--$

Ma cáw+nā, Ms njáw+rā, Mb anjaw+da, $P$ cēw, H cēu, $Z$ ceu

179. to take out: *pat

Ma pat, Ms pat, Mb pat, $\mathrm{P}$ pat, $\mathrm{H}$ pata

180. tamarind: * cin

$M a$ cīn+nā, Ms cīn+dà, $M b$ acin+da, $P$ mòcīn, $H$ mīsīn, $L$ maicín, $Z$ minjin

181. ten: *gup

$\mathrm{P}$ gū6, $\mathrm{H}$ gub, $\mathrm{N}$ gwub, $\mathrm{Z}$ gub

182. three: *hindi

Ma fì̀dî, Ms hīndī, Mb hindi, $\mathrm{P}$ hínjī, $\mathrm{H}$ híndī, $\mathrm{N}$ híndì?, $\mathrm{Z}$ hindi

183. throat, voice: $*_{\text {der }}$

Ma dèl+là, Ms dèl+là, $\mathrm{Mb}$ del+a, $\mathrm{H}$ dîràì, $\mathrm{Z}$ der

184. to throw: *g-

Ma gi, Ms gi, Mb ge, $\mathrm{P}$ gie, $\mathrm{H}$ ge, $\mathrm{Z} 2$ ge

185. throwing knife: *b-r

Ma bìl+lā, Ms bíl+nā, Mb abĩl+a, $P$ pòrà, $H$ brà

186. time: *ri

Ms lī nà, $\mathrm{P}$ rī, H ri

187. tongue: *si

Ma sīn+nā, Ms sīn+dá, Mb sin+a, P Jīdì , H sílé, $N$ sīlī, $Z$ cil

188. tooth: *s-

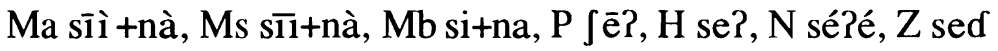


189. tree, wood: *gu

Ma gú+nā, Ms gú+nā, Mb aggu+na, $\mathrm{P}$ gū, $\mathrm{H}$ úgù, $N$ ūkū, $\mathrm{Z}$ ago

190. urine: *jumbur

Ma zùmūū+rā, Ms súmúútrā, Mb sumu+ra, $P$ jòbūr, L jubur

191. to vomit: *vin

$M a$ vin, $M s$ vin, $M b$ vin, $L$ vìnè?è

192. vulture: *bak

Ma băk+nā, Ms bàk+jà, Mb abah+a, P2 bwok, L bok

193. warthog: *z-n

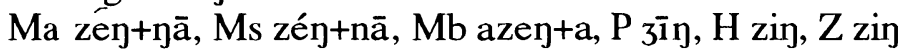

194. to wash: *mbus

Ma mus, Ms mbus, Mb mbus, $\mathrm{P}$ mbi, $\mathrm{H}$ mbis, $\mathrm{L}$ mbus, $\mathrm{Z}$ mbus

195. to wash grain: *sal

Ms sal, P sal, H sal

196. wasp: *vin

Ms vì yvīj $+\eta \bar{a}, M b$ vivin+a, $H$ vì vì

197. to watch: *gol

Ms gol, Mb gol, H gól

198. water: *mb-

Ms mbòó+nā, Mb mbyo+na, P mbi, H mbi, Z mbi

199. what: *mi

Ma mì gé, Ms mī, Mb me, P mā , P2 mi su, L mi

200. to whistle: $*$ f-t

Ms fet, Mb ge fet, $\mathrm{P}$ fadiw, $\mathrm{H}$ fidiu

201. wind: *simbet

Ma símēê+nā, Ms sémét+nā, Mb simet+na, $\mathrm{P} 2$ simbed, $\mathrm{H}$ símbēè, Z2 simed

202. wound, sore: *mbir

Ma mīl+lā, Ms mbìl+là, Mb mbĩl+a, P mbīr, $\mathrm{H}$ mbìr

203. year: *kim

Ms kīm+bá, P kīm, H kìm, Z2 kim

204. yesterday: *k-mb-

Ma kāmā+tā, Mb kama, P kúm, L kúmbu, kəmbat 


\section{REFERENCES}

Barreteau, Daniel. 1987. "Un essai de classification lexico-statistique des langues de la famille tchadique parlées au Cameroun." In Daniel Barreteau (ed.), Langues et cultures dans le bassin du lac Tchad, pp. 43-77. Paris: Editions de l'ORSTOM.

Caïtucoli, Claude. 1983. Lexique Masa. Paris: Agence de coopération culturelle et technique; Yaoundé, Cameroon: CERDOTOLA, Equipe des langues tchadiennes.

Caprile, J.-P. and Hermann Jungraithmayr. 1973. "Inventaire provisoire des langues 'tchadique' parlées sur le territoire de la Republique du Tchad." Africana Marburgensia 6(2):31-48.

Cooper, Koye. 1984. Lexique Zime-Français. Sarh, Chad: Centre d'Études Linguistiques.

Court, Pierre. 1985. Lexique Zime-Français. Pala, Chad: Mission Catholique.

Dieu, Michel and Patrick Renaud. 1983. Situation linguistique en afrique centrale. Inventaire préliminaire: le Cameroun. Yaoundé, Cameroon: Délégation générale à la recherche scientifique et technique, Institut des sciences humaines.

Fédry, Jacques. 1971. Dictionnaire dangaléat (Tchad). Lyon: Afrique et Langage.

Franco, Nicolas. 1970. “Vocabulaire Marba.” Unpublished ms., Montreal.

Greenberg, Joseph. 1963. The Languages of Africa. Bloomington: Indiana University.

Hoffmann, Carl. 1971. "Provisional check list of Chadic languages." Chadic Newsletter (Marburg, special issue, January), Chadic Working Group, West African Linguistic Society, 2-10.

Hufnagel, Ruth. 1986. "Comparative Reconstruction of Zime, Kado, and Peve." Unpublished ms., Mission Protestante, Kelo, Chad.

Jungraithmayr, Hermann. 1968. "A comparative wordlist of the Ron languages (Southern Plateau, Northern Nigeria).” Africana Marburgensia 1(2):3-12. 
Jungraithmayr, Hermann. 1970. Die Ron-Sprachen: tschadohamitische Studien in Nordnigerien. Gluckstadt: Augustin.

Jungraithmayr, Hermann. 1978a. "The Zime dialect cluster ("Kado", "Dari”) in Southern Chad: its verbal aspect system." Afrika und Übersee 61:1-27.

Jungraithmayr, Hermann. 1978b. "Présentation d'un conte en sibine (sumray) texte, notes et vocabulaire." In H. Jungraithmayr and J.-P. Caprile (eds.),Cinq textes tchadiques, pp. 177-211. Berlin: Reimer.

Jungraithmayr, Hermann. 1981. "Inventaire des langues tchadiques." In Gabriel Manessy (ed.), Les langues dans le monde ancien et moderne. 1. Les langues de l'Afrique Subsaharienne, pp. 407-413. Paris: CNRS.

Jungraithmayr, Hermann. 1990. Lexique Mokilko. Berlin: Reimer.

Jungraithmayr, Hermann and Kiyoshi Shimizu. 1981. Chadic Lexical Roots. Vol. II: Tentative reconstructions, grading and distribution. Berlin: Reimer.

Jungraithmayr, Hermann and Dymitr Ibriszimow. 1994. Chadic Lexical Roots. Berlin: Reimer.

Kieschke, Regine. 1990. “Esquisse phonologique du Mesme.” Thesis. Université de la Sorbonne Nouvelle Paris III.

Kraft, Charles. 1974. "Reconstructions of Chadic Pronouns 1: Possessive, Object, and Independent Sets--An Interim Report." In Erhard Voeltz (ed.), The Third Annual Conference on African Linguistics (April 7-8, 1972), pp. 69-94. Bloomington: Indiana University.

Kraft, Charles. 1981. Chadic Wordlists. Berlin: Reimer.

Lukas, Johannes. 1936. Die Logone-Sprache im zentralen Sudan. Mit Beitragen aus dem Nachlass von Gustav Nachtigal. Leipzig: Deutsche Morgenländische Gesellschaft.

Lukas, Johannes. 1939. "Die Sprache der Buduma im Zentralen Sudan.” Auf Grund eigener Studien und des Nachlasses von Gustav Nachtigal. Leipzig: Deutsche Morgenländische Gesellschaft.

Lukas, Johannes. 1941. "Deutsche Quellen zur Sprache der Musgu in Kamerun." Beihefte zur Zeitschrift für Eingeborenen-Sprachen 24. 
Meyer-Bahlberg, Hilke. 1972. Studien zur Morphologie und Syntax des Musgu. Hamburg: Buske.

Newman, Paul. 1977a. "Lateral fricatives ('hlaterals') in Chadic.” In Paul Newman and Roxana Ma Newman (eds.), Papers in Chadic Linguistics, pp. 107-19. Leiden: Afrika-Studiecentrum, Leiden University.

Newman, Paul. 1977b. "Chadic classification and reconstructions." Afroasiatic Linguistics 5(1): 1-42.

Newman, Paul. 1978. "Chado-Hamitic 'adieu': new thoughts on Chadic language classification." In P. Fronzaroli (ed.), Quaderni di Semitistica 5: Proceedings of the Second International Congress on Hamito-Semitic Linguistics., pp. 389-97. Florence: Istituto de linguistica e di lingue orientali.

Newman, Paul. 1990. Nominal and Verbal Plurality in Chadic. Dordrecht: Foris Publications.

Newman, Paul. 1992. "Chadic languages." In W. Bright (ed.), International Encyclopedia of Linguistics, pp. 253-54. Oxford: Oxford University Press.

Newman, Paul, and Roxana Ma. 1966. "Comparative Chadic: phonology and lexicon.” Journal of African Languages 5:218-51.

Noss, Philip. 1990. "Statistics, identity, and dialect. The Zime group of Chadic languages.” Unpublished ms., United Bible Society, Yaoundé, Cameroon.

Price, Colin. 1968. “Azumeina-English Dictionary.” Unpublished ms., University of London.

Platiel, Susanne. 1968. "Esquisse d'une étude du Musey." Bulletin de la Société pour l'Études des Langues Africaines 6.

Rapp, Eugen L. and C. Mühle. 1969. Dictionary of the Glavdá language,Vol. II: English-Glavdá. Frankfurt: Bible Society.

Sachnine, Michka. 1982. Le Lame (Nord-Cameroun). Paris: SELAF.

Schuh, Russell. n.d. Field notes on Gidar. Ms., University of California, Los Angeles.

Schuh, Russell. 1978. Bole-Tangale Languages of the Bauchi Area (Northern Nigeria). Berlin: Reimer. 
Schuh, Russell. 1981a. A Dictionary of Ngizim. Berkeley: University of California Press.

Schuh, Russell. 1981b. "Using dialect geography to determine prehistory: a Chadic case study." Sprache und Geschichte in Afrika 3:201-50.

Schuh, Russell. 1995. “A Grammar of Miya.” Unpublished ms., University of California, Los Angeles.

Shimizu, Kiyoshi. 1978. "The southern Bauchi group of Chadic languages-a survey report." Africana Marburgensia, Special Issue 2.

Shryock, Aaron. 1995. “A Dictionary of Musey.” Unpublished ms., University of California, Los Angeles.

Tourneux, Henry. 1990. "Place du Masa dans la famille Tchadique." In H. Mukarovsky (ed.), Proceedings of the Fifth International Hamito-Semitic Congress (Vienna, 1987), Vol. 1, pp. 249-260. Wein: Afro-Pub.

Venberg, Rodney. 1975. "Phonemic statement of the Peve language." Africana Marburgensia 8:26-43.

Westermann, Dietrich and M. A. Bryan. 1952. The Languages of West Africa. Handbook of African Languages, Part 2. London: Oxford University Press.

Wolff, Eckhart. 1983. A Grammar of the Lamang language. Gluckstadt: Augustin.

Department of Linguistics

University of California

Los Angeles, CA 90095

shyrock@humnet.ucla.edu
[Received May 15, 1996; provisional acceptance August 15, 1996; final version accepted June 12, 1997] 